\title{
Sequential Changes in AMPA Receptor Targeting in the Developing Neocortical Excitatory Circuit
}

\author{
Julia Brill and John R. Huguenard \\ Department of Neurology and Neurological Sciences, Stanford University School of Medicine, Stanford, California 94305
}

\begin{abstract}
Many principal neurons undergo an early developmental switch from GluR2-lacking to GluR2-containing synaptic glutamate receptors. We tested the generality and timing of the GluR2 switch in excitatory neurons of rat somatosensory cortex. Previous studies show that the switch occurs between postnatal day 14 (P14) and P16 in layer 5 pyramidal neurons. We show, using sensitivity to intracellular spermine, that a similar switch occurs between P12 and P14 in layer 2/3 pyramidal cells and between P7 and P8 in layer 4 stellate cells. The presence of GluR2-lacking receptors in layer 2/3 pyramidal cells before P12 was confirmed by demonstrating sensitivity to blockade by 1-naphthylacetyl-spermine and large single-channel conductances. GluR2 and the postsynaptic protein PSD95 show progressive colocalization in tissue from P10, P14, and P24 rats, mirroring electrophysiological developments. To distinguish whether changes in GluR2 expression or targeting underlie the switch, we characterized dendritic AMPA receptor responses using focal photolysis of caged glutamate. Contrary to synaptic responses, dendritic responses at all ages studied (P6-P40) were characteristic of GluR2-containing receptors. In addition, dendritically and synaptically evoked responses showed a corresponding decrease in NMDA/AMPA ratios in pyramidal cells, suggesting parallel mechanisms that regulate neuronal calcium levels. These data suggest that the GluR2 switch results from changes in AMPA receptor targeting during early postnatal development, and that rather than following the laminar sequence of cortical development, it proceeds sequentially from layer 4 to layer $2 / 3$ and finally to layer $5 \mathrm{~b}$.
\end{abstract}

Key words: AMPA receptor; somatosensory cortex; development; rectification; polyamine; pyramidal cell

\section{Introduction}

AMPA receptors are the main mediators of fast excitatory neurotransmission in the CNS (Dingledine et al., 1999). They are homotetrameric or heterotetrameric assemblies of GluR1 through GluR4 subunits (or, synonymously, GluRA-D) (Keinanen et al., 1990; Mano and Teichberg, 1998; Rosenmund et al., 1998). AMPA receptors lacking GluR2 subunits, as well as kainate receptors, are $\mathrm{Ca}^{2+}$ permeable (Hollmann et al., 1991) and are modulated by polyamines. Intracellular polyamines preferably bind to receptors at depolarized membrane potentials and, when bound, block the channel pore. This results in inwardly rectifying current/voltage ( $I / V)$ relationships (Verdoorn et al., 1991; Kamboj et al., 1995; Koh et al., 1995). AMPA receptors containing one or more GluR2 subunits are $\mathrm{Ca}^{2+}$ impermeable and are not modulated by polyamines (Washburn et al., 1997). Receptor interacting proteins can be secondary determinants of polyamine modulation; one example is the association of stargazin with GluR2lacking receptors, which attenuates polyamine block (Soto et al., 2007). Regulation of synaptic strength involving distinct populations of AMPA receptors is central to the expression of various

Received July 10, 2008; revised 0ct. 27, 2008; accepted Nov. 4, 2008.

This work was supported by National Institute of Neurological Disorders and Stroke Grant NS12151 (J.R.H.) and an American Epilepsy Society postdoctoral fellowship (J.B.). We thank Isabel Parada for expert assistance with immunostaining.

Correspondence should be addressed to Dr. John R. Huguenard, Department of Neurology and Neurological Sciences, Stanford University School of Medicine, 300 Pasteur Drive, Room M016, Stanford, CA 94305. E-mail: john.huguenard@stanford.edu.

DOI:10.1523/JNEUROSCI.3229-08.2008

Copyright $\odot 2008$ Society for Neuroscience 0270-6474/08/2813918-11\$15.00/0 forms of plasticity (Hayashi et al., 2000; Plant et al., 2006). Phosphorylation and other posttranslational modifications of the receptor subunits themselves or their interacting proteins play important roles in synaptic targeting (Matsuda et al., 1999; Chetkovich et al., 2002; Esteban et al., 2003; Mauceri et al., 2004; Liu and Cull-Candy, 2005; Guire et al., 2008).

Layer 5 neocortical pyramidal neurons in rats undergo a developmental switch around $\mathrm{P} 15$ in which immature, $\mathrm{Ca}^{2+}$ permeable, GluR2-lacking AMPA receptors are replaced in synapses by mature GluR2-containing receptors (Kumar et al., 2002; Shin et al., 2005). We investigated whether the GluR2 switch also occurs in layer 2/3 pyramidal cells and layer 4 stellate cells (i.e., whether it is a general property of principal neocortical neurons). We found that the AMPA receptor subunit switch in layer $2 / 3$ pyramidal neurons precedes that in layer $5 \mathrm{~b}$ neurons, whereas layer 4 stellate cells express mainly GluR2-containing AMPA receptors already at P8. Thus, timing of the GluR2 switch does not correspond to the ontogenetic age of principal neurons. We also show that inwardly rectifying AMPA receptors are absent from extrasynaptic sites of pyramidal cells. In addition, NMDA/AMPA ratios were more than twofold higher at extrasynaptic than at synaptic sites, and the ratios at both sites decreased during development. Expression of GluR2-containing AMPA receptors and downregulation of the NMDA/AMPA ratios would work in concert to progressively limit synaptically driven calcium influx during neocortical development.

\section{Materials and Methods}

Slice/tissue preparation. All experiments were performed according to protocols approved by the Stanford Institutional Animal Care and Use 
Committee. Sprague Dawley rats aged postnatal day 6 (P6) to P50 were deeply anesthetized using $50 \mathrm{mg} / \mathrm{kg}$ sodium pentobarbital, and brains were removed and immediately transferred to ice-cold sucrose solution containing (in mM) 234 sucrose, 11 glucose, $24 \mathrm{NaHCO}_{3}, 2.5 \mathrm{KCl}, 1.25$ $\mathrm{NaH}_{2} \mathrm{PO}_{4}, 2 \mathrm{MgSO}_{4}$, and $0.5 \mathrm{CaCl}_{2}$, equilibrated with a $95 \% \mathrm{O}_{2} / 5 \% \mathrm{CO}_{2}$ mixture. Coronal neocortical slices $(400 \mu \mathrm{m})$ were sectioned on a VT1000S Vibratome (Leica) at $4^{\circ} \mathrm{C}$ in sucrose solution and transferred into a holding chamber filled with artificial CSF (ACSF; in mM: $126 \mathrm{NaCl}$, $26 \mathrm{NaHCO}_{3}, 2.5 \mathrm{KCl}, 1.25 \mathrm{NaH}_{3} \mathrm{PO}_{4}, 2 \mathrm{CaCl}_{2}, 2 \mathrm{MgCl}_{2}$, and 10 glucose, $\mathrm{pH} 7.4$, equilibrated with $\left.95 \% \mathrm{O}_{2} / 5 \% \mathrm{CO}_{2}\right)$. After a recovery period of $1 \mathrm{~h}$ at $32^{\circ} \mathrm{C}$, the holding chamber containing the slices was removed from the water bath and allowed to cool to room temperature.

Electrophysiology. Slices were transferred to a recording chamber and constantly superfused with oxygenated ACSF at a rate of $\sim 2 \mathrm{ml} / \mathrm{min}$. All experiments were conducted at room temperature, and all cells recorded were located in primary somatosensory cortex in trunk and limb areas. The location of the six layers of the primary somatosensory cortex was determined from an overview image at $5 \times$ magnification, and neurons were visualized at $63 \times$ magnification using differential contrast optics with an Axioskop 2 FS microscope (Carl Zeiss). Pyramidal cells were identified based on their large size, tear-shaped morphology, and thick apical dendrite. In addition, cells were routinely filled with $0.3 \% \mathrm{w} / \mathrm{v}$ biocytin for further verification of their identity. Whole-cell recordings in voltage-clamp mode were obtained using borosilicate glass electrodes with a tip resistance of $2-4 \mathrm{M} \Omega$. The pipette solution contained (in $\mathrm{mm}$ ) 130 Cs-gluconate, $8 \mathrm{CsCl}, 10$ HEPES, 4 EGTA, and $0.01[\mathrm{~N}-(2,6-$ dimethylphenylcarbamoylmethyl) triethylammonium bromide] (QX314), pH 7.3 adjusted with $\mathrm{CsOH}(290 \mathrm{mOsm}$ ) for all experiments except recordings of spontaneous EPSCs, in which we used (in mM) 120 K-gluconate, $11 \mathrm{KCl}, 1 \mathrm{MgCl}_{2}, 1 \mathrm{CaCl}_{2}, 10 \mathrm{HEPES}$, and $10 \mathrm{EGTA}, \mathrm{pH} 7.3$, adjusted with $\mathrm{KOH}$. For measurements of $I / V$ relationships and pairedpulse ratios (PPRs), $50 \mu \mathrm{M}$ spermine was included in the pipette solution. Unless indicated otherwise, NMDA receptor-mediated conductances were blocked by bath application of either $100 \mu \mathrm{M}$ DL-AP-5 (Tocris) or 50 $\mu \mathrm{M}$ D-AP-5 (Ascent Scientific); $\mathrm{GABA}_{\mathrm{A}}$ receptor-mediated conductances were blocked using $50 \mu \mathrm{M}$ picrotoxin (Tocris). Only recordings in which the series resistance was $<25 \mathrm{M} \Omega$ were included in the data analysis, and membrane potentials were corrected for a liquid junction potential of 20 $\mathrm{mV}$ (all voltages given subsequently include liquid junction potential correction). A concentric bipolar electrode (75 $\mu \mathrm{m}$ diameter; CBXRC75; Frederick Haer) was positioned on-column in layer 4 for electrical stimulation of layer $2 / 3$ neurons, in layer $2 / 3$ or upper layer 4 for electrical stimulation of layer 5 neurons, and in layer 4 or 5 a for layer 4 neurons. Synaptic activity was evoked by delivering constant current pulses of $100-500 \mu \mathrm{A}$ for $100 \mu$ s at intervals between 5 and 20 s. Stimulation intensities were selected to correspond to $\sim 2 \times$ threshold for a detectable response. Signals were amplified with a Multiclamp 700A amplifier, sampled at $10 \mathrm{kHz}$, filtered at $3 \mathrm{kHz}$, acquired using a Digidata 1320A digitizer, and analyzed using pClamp9 (all from Molecular Devices).

Focal photolysis of caged glutamate. A pulsed $355 \mathrm{~nm}$ UV laser beam (DPSS Lasers) was directed into the back aperture of the $63 \times$ microscope objective and was controlled with mirror galvanometers (model 6210; Cambridge Technology) using a locally developed software program. Focal photolysis of 4-methoxy-7-nitroindolinyl (MNI)-caged glutamate (100 $\mu \mathrm{M}$; Tocris) was triggered by UV light pulses $(50-500 \mu \mathrm{s}$, unless indicated otherwise). MNI-caged glutamate was supplied in a $30 \mathrm{ml}$ recirculating bath solution. To find a location for photolysis, we scanned areas in a $100-500 \mu \mathrm{m}$ radius surrounding the soma of the recorded cell until we robustly detected graded, short-latency $(<3 \mathrm{~ms})$ "direct dendritic responses" that were abolished by moving the laser beam $>10-20$ $\mu \mathrm{m}$ laterally. Our experience shows that MNI-glutamate remains stable for up to several hours (Deleuze and Huguenard, 2006; Jin et al., 2006). We typically exchanged the $30 \mathrm{ml}$ recirculating bath solution after 3-4 h or sooner if we detected significant rundown of direct dendritic responses.

$I / V$ relationships were assayed by evoking EPSCs or direct dendritic responses from holding potentials of $-60,-45,-30,-15,0,15,30,45$, and $60 \mathrm{mV}$ (after correction for liquid junction potential). At least two, but typically three to five direct dendritic responses and six to eight synaptic responses were averaged, and synaptic failures were excluded. Rectification indices were defined as the ratio of the slope at positive $(0-60 \mathrm{mV})$ and negative $(-60$ to $0 \mathrm{mV})$ holding potentials. Slopes were derived by linear regression of maximal response amplitudes. Voltagedependent unblocking was assayed by measuring PPRs (100 ms interstimulus intervals) of EPSCs at holding potentials of -60 and $+50 \mathrm{mV}$. Voltage-dependent blocking indices were calculated by dividing the PPR at $+50 \mathrm{mV}$ by the PPR at $-60 \mathrm{mV}$. Ratios $>1$ indicated voltagedependent unblocking.

Pharmacological experiments. For testing sensitivity to extracellular polyamines, $30 \mathrm{~min}$ of spontaneous activity were recorded in voltageclamp mode at a holding potential of $-65 \mathrm{mV}$ in the presence of D-APV and picrotoxin. After $10 \mathrm{~min}$ in regular ACSF, the bath solution was changed to ACSF supplemented with $200 \mu \mathrm{M}$ 1-naphthyl-acteylspermine (NAS; Sigma-Aldrich) for $10 \mathrm{~min}$, and finally changed back to regular ACSF for $10 \mathrm{~min}$. The last $5 \mathrm{~min}$ of each interval were analyzed, to allow for a 5 min washin and washout of NAS. For control experiments, 30 min of spontaneous activity in regular ACSF was recorded, and equivalent time points were analyzed (i.e., minutes 5-10, 15-20, and 25-30). EPSCs were detected and quantified using locally written software.

Nonstationary fluctuation analysis. Spontaneous EPSCs recorded during a $10 \mathrm{~min}$ period at a holding potential of $-65 \mathrm{mV}$ in the presence of D-APV and picrotoxin were identified and aligned to their peak. An average trace was computed, and its scaled decay phase was subtracted from each individual trace. The background variance was calculated from event-free portions of the recording and subtracted. The average background-subtracted variance of these synaptic fluctuations was plotted against the amplitude of the averaged EPSC and fit to a parabolic curve using the following equation: $\sigma^{2}=i I-I^{2} / N$, where $i$ is the singlechannel current, $I$ is the peak of the mean current, and $N$ is the number of channels activated at the peak of the mean current (Benke et al., 2001). The single-channel conductance $(\gamma)$ was calculated using $\gamma=i / V(V=$ holding potential $=-65 \mathrm{mV}$ assuming a reversal potential of $0 \mathrm{mV}$ ).

NMDA/AMPA ratios. Cells were held at membrane potentials of +50 and $-60 \mathrm{mV}$ in the presence of QX314 in the internal solution and picrotoxin in the ASCF. EPSCs and direct dendritic responses were evoked as described for $I / V$ relationships, and 6-15 sweeps were averaged. The ratio of the peak amplitudes at $+50 \mathrm{mV}$ (typically within 20 $\mathrm{ms}$, predominantly NMDA receptor mediated) and at $-60 \mathrm{mV}$ (typically within $5 \mathrm{~ms}$, predominantly AMPA receptor mediated) was calculated.

Immunohistochemistry. Paraformaldehyde-fixed and cryoprotected tissue was frozen and cut into $40 \mu \mathrm{m}$ sections on a HM400 cryotome (Microm). Sections were blocked in PBS and 10\% normal goat serum for $1 \mathrm{~h}$ at room temperature and incubated in a primary antibody overnight at $4^{\circ} \mathrm{C}$ (rabbit polyclonal anti-GluR2, mouse monoclonal PSD95; $1 \mu \mathrm{g} /$ $\mathrm{ml}$; Millipore Bioscience Research Reagents). Sections were rinsed twice at room temperature for $5 \mathrm{~min}$ and incubated in a solution containing fluorescent secondary antibodies at room temperature for $1 \mathrm{~h}(2 \mu \mathrm{g} / \mathrm{ml}$ goat anti-rabbit Alexa Fluor 488 and $2 \mu \mathrm{g} / \mathrm{ml}$ goat anti-mouse IgG Alexa Fluor 568; Invitrogen). After rinsing twice in PBS for $5 \mathrm{~min}$, sections were mounted on SuperfrostPlus slides (Thermo Fisher Scientific) and coverslipped using Vectashield mounting medium (Vector Laboratories). " $Z$ stacks" $(25 \times 25 \times 5 \mu \mathrm{m})$ of 12 images (at a vertical spacing of $417 \mathrm{~nm}$ ) were captured on an LSM510 confocal laser-scanning microscope (Carl Zeiss). Locations of $z$-stack images were chosen randomly. $X, Y$, and $Z$ coordinates of all GluR2-positive (red) and PSD95-positive (green) objects consisting of three or more contiguous voxels were analyzed using volocity software (Improvision). To calculate the degree of colocalization of GluR2 with PSD95, we identified and counted the number of GluR2positive objects in $0.05 \mu \mathrm{m}$ shells around each PSD95-positive object using a customized software. The small volume of the innermost shell precluded a statistically valid determination of colocalization at distances of $<0.05 \mu \mathrm{m}$ in layer $2 / 3$. Particle density was fit to a single-exponential decay function; in layer $2 / 3$, the innermost shell was excluded from the analysis, and the fit was extrapolated to $x=0$. Uniformity of antibody penetration and secondary staining was confirmed by demonstrating that density of GluR2- and PSD95-positive particles did not change as a function of depth in the section. To minimize edge effects, GluR2 particle 


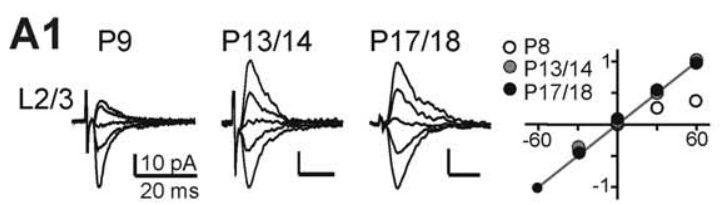

A2
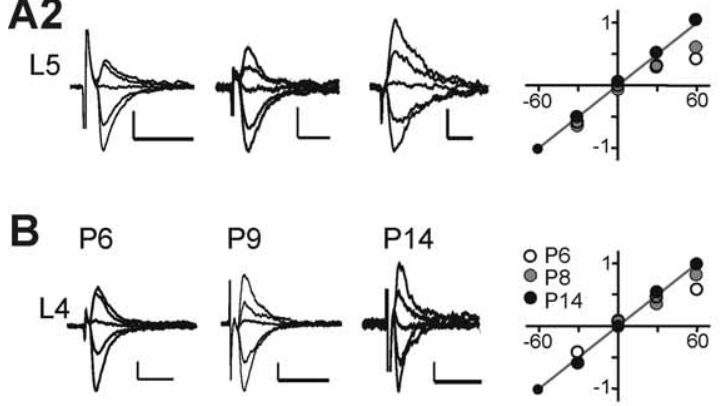

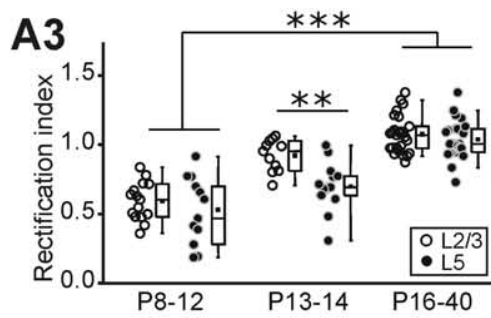

D1
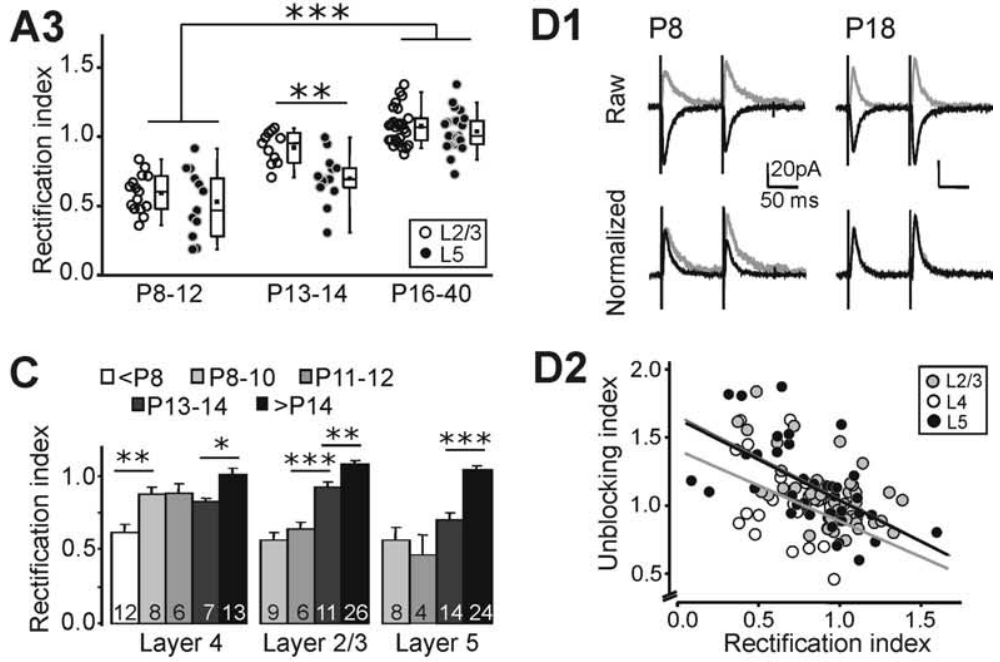

D2

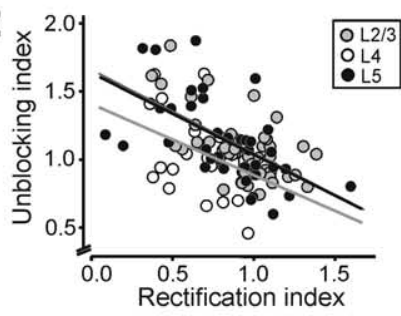

Figure 1. Inwardly rectifying AMPA receptors in immature principal neurons. A1, A2, Left three panels, Representative examples of EPSCs evoked from holding potentials of $-60,-30,0,30$, and $60 \mathrm{mV}$ in layer 2/3 (A1) and layer 5 (A2) pyramidal cells of animals aged P9, P13/P14, and P17/P18. Recordings were obtained with $50 \mu \mathrm{m}$ spermine in the patch pipette. Calibration: $20 \mathrm{~ms}, 10$ pA. Right, I/V curves derived from normalized EPSC amplitudes of the traces shown in the left panels (white circles, P9; gray circles, P13-P14; black circles, P17-P18). Layer 2/3 cells at P9 and layer 5 cells at P9 and P13-P14 show inward rectification. Straight lines are added to indicate linear I/V relationships. A3, Summary data for all rectification indices (RIs) measured in layer 2/3 (L2/3; open circles) and layer 5 (L5; filled circles) cells for animals aged P8 -P12, P13-P14, and P16-P40. Boxes to the right of individual data points show mean (open square), median (central horizontal line), and 25th and 75th (box) and 5th to 95th (whiskers) percentiles. The switch from inwardly rectifying to linear $/ / V$ relationships in layer $2 / 3$ cells precedes the switch in layer 5 cells. ${ }^{* *} p<0.001$; ${ }^{* * *} p<0.0001$. B, Same as $\boldsymbol{A} 1$ and $\boldsymbol{A 2}$, but for layer 4 stellate cells from animals aged P6, P9, and P14. Calibration: $20 \mathrm{~ms}, 10 \mathrm{pA}$. Left, I/V curves derived from normalized traces for P6 (white circles), P9 (gray circles), and P14 (black circles). The P6 cell shows inward rectification. C, Developmental changes in Rls in principal neurons of layer 4, layer 2/3, and layer 5 in animals aged $<$ P8, P8 -P10, P11-P12, P13-P14, and >P14 (layer 2/3 and layer 5 from same dataset as in A3). Rls in all neocortical layers change during early postnatal development from inward rectification to linearity. The greatest Rl increases occur around P8 in layer 4 cells, around P12/P13 in layer 2/3 cells, and around P14 in layer 5 cells. In layer 4 and layer 2/3 cells, there is a second, minor increase around P14. * $p<$ $0.01 ;{ }^{* *} p<0.001 ;{ }^{* * *} p<0.0001$. Numbers at the bottom of columns indicate sample size. Error bars indicate SEM. D1, Paired pulses (100 ms) were delivered from holding potentials of $-60 \mathrm{mV}$ (black lines) and $+50 \mathrm{mV}$ (gray lines). Raw traces (top) from representative layer 2/3 pyramidal cells of a P8 and a P18 rat are shown. Normalized traces (bottom) show that at P8 the second pulse at $+50 \mathrm{mV}$ is relatively larger than at $-60 \mathrm{mV}$, whereas PPRs at P18 do not depend on the holding potential. Calibration: $50 \mathrm{~ms}, 20 \mathrm{pA}$. D2, Correlation between rectification index ( $x$-axis) and unblocking index ( $y$-axis) for layer 2/3 (L2/3; gray circles) and layer 5 (L5; black circles) pyramidal cells of P8-P40 rats and layer 4 stellate cells (L4; white circles) of P6 -P18 rats. The solid line indicates fits by linear regression [dark gray, layer 2/3; black, layer 5 (largely overlaps with layer 2/3 regression line); light gray, layer 4).

density analysis was restricted to PSD95-positive particles interior to the stack and $>1 \mu \mathrm{m}$ from any edge.

\section{Results}

Inwardly rectifying AMPA receptors in immature excitatory cells in layers $2 / 3,4$, and $5 b$

We recorded $I / V$ curves from 52 layer $2 / 3$ pyramidal cells, 46 layer 4 stellate cells, and 50 layer $5 \mathrm{~b}$ pyramidal cells in the primary somatosensory cortex of rats aged P6-P40. Linear $I / V$ curves are indicative of GluR2-containing, calcium-impermeable AMPA receptors, whereas increasing inward rectification is indicative of higher relative proportions of GluR2-lacking, calciumpermeable AMPA receptors. For recordings in layer 5b, the stimulation electrode was placed on-column in layer $2 / 3$ (but occasionally in upper layer 4) to permit a preferential activation of layer $2 / 3$ to layer $5 b$ projections. As reported previously (Kumar et al., 2002; Shin et al., 2005), layer 5 pyramidal cells switched from inwardly rectifying to linear $I / V$ relationships around P15 (rectification index: $\mathrm{P} 8-\mathrm{P} 14,0.62 \pm 0.04, n=26$; P16-P40, $1.04 \pm 0.03, n=24 ; p<0.0001$ ) (Fig. 1A2). For recordings in layer $2 / 3$ pyramidal cells, the stimulation electrode was placed on-column in layer 4 . Because layer $2 / 3$ receives the majority of excitatory inputs from layer 4 (Dantzker and Callaway, 2000; Shepherd et al., 2003; Bureau et al., 2004), and descending layer $2 / 3$ pyramidal cell axons usually do not arborize extensively in layer 4 (Petersen and Sakmann, 2001; Larsen and Callaway, 2006), layer 4 stimulation will result mainly in activation of afferents from that layer. The examples in Figure $1 A 1$ and the summary data in Figure 1, $A 3$ and $C$, show that a similar developmental switch occurred in layer $2 / 3$ pyramidal neurons, but it preceded the switch in layer 5 neurons by $\sim 2 \mathrm{~d}$ (rectification index: P8-P12, $0.59 \pm 0.04, n=15 ; \mathrm{P} 13-\mathrm{P} 40,1.03 \pm 0.02, n=$ $37 ; p<0.0001)$. In slices from P13 and P14 rats, we found a significant difference in the average rectification indices between layer 2/3 and layer 5b pyramidal cells (layer 2/3: $0.92 \pm 0.03, n=$ 11; layer 5: $0.70 \pm 0.05, n=14 ; p<0.01$ ) (Fig. 1A3). Comparisons of rectification indices between layer $2 / 3$ and 5 pyramidal cells in slices from younger (P8-P12) or older (P16-P40) animals showed no significant differences (Fig. 1A3, Table 1). For layer 4 recordings, the stimulation electrode was placed oncolumn below the recorded cell to activate both intralaminar and thalamocortical axons (Feldmeyer et al., 1999; Thomson et al., 2002). Figure $1 B$ shows example traces from representative layer 4 stellate cells at P6, P9, and P14 and the corresponding $I / V$ curves. We measured rectification indices in 46 layer 4 stellate cells in slices from rats aged P6-P19 by electrical stimulation of adjacent cortical areas (Table 2). Before P8, layer 4 cells had inwardly rectifying $I / V$ curves (rectification index, $0.61 \pm 0.05 ; n=$ 12 ) and continued to display slight inward rectification between P8 and P14 $(0.81 \pm 0.05 ; n=24)$. After P14, they displayed linear $I / V$ relationships $(0.98 \pm 0.03 ; n=9)$ (Fig. $1 C)$. It should be noted that there was an additional, minor change in rectification indices around P14 in layer 2/3 and layer 4 cells (Fig. 1C).

Intracellular polyamines preferentially block GluR2-lacking AMPA receptors at depolarized potentials, and this blockade is partially relieved in an activity-dependent manner (Rozov and Burnashev, 1999; Bagal et al., 2005). We used this phenomenon as further verification of the presence of GluR2-lacking AMPA receptors in immature pyramidal cells. Paired synaptic stimuli 
Table 1. Rectification indices (RIs) for synaptic and dendritic AMPA receptor-mediated responses in layer 2/3 and layer 5 pyramidal cells in slices from rats aged P8-P12, P13-P14, and P16-P40

\begin{tabular}{|c|c|c|c|c|c|}
\hline & \multicolumn{2}{|l|}{ Layer 2/3 } & \multicolumn{2}{|l|}{ Layer 5} & \multirow{2}{*}{$\begin{array}{l}\text { Layer } 2 / 3 \text { vs layer } 5 \\
p\end{array}$} \\
\hline & $\mathrm{RI} \pm \mathrm{SEM}(n)$ & $p$ & $\mathrm{RI} \pm \mathrm{SEM}(n)$ & $p$ & \\
\hline \multicolumn{6}{|l|}{ Synaptic } \\
\hline P8-P12 & $0.593 \pm 0.035(15)$ & $* * *$ & $0.531 \pm 0.070(12)$ & tt & $\dagger$ \\
\hline P13-P14 & $0.922 \pm 0.035(11)$ & $* * *$ & $0.700 \pm 0.046(14)$ & $* * *$ & * \\
\hline P16-P40 & $1.075 \pm 0.026(26)$ & $* *$ & $1.037 \pm 0.028(24)$ & $* * *$ & $\dagger$ \\
\hline \multicolumn{6}{|l|}{ Dendritic } \\
\hline P8-P12 & $1.189 \pm 0.059(17)$ & + & $1.288 \pm 0.061(13)$ & $\dagger$ & $t$ \\
\hline P13-P14 & $1.243 \pm 0.053(18)$ & tt & $1.156 \pm 0.059(13)$ & $\dagger$ & $\dagger$ \\
\hline P16-P40 & $1.073 \pm 0.040(30)$ & $t$ & $1.148 \pm 0.050(23)$ & $\dagger$ & $t$ \\
\hline
\end{tabular}

Numbers in parentheses indicate the number of cells. Statistical significance (unpaired $t$ test) is as follows: ${ }^{\dagger} p>0.05 ;{ }^{+\dagger} p>0.01 ;{ }^{*} p<0.01 ;{ }^{* *} p<0.001$; ${ }^{* * *} p<0.0001$.

Table 2. RIs for synaptic AMPA receptor-mediated responses in layer 4 stellate cells in slices from rats aged P8 -P12, P13-P14, and P16-P19

\begin{tabular}{lll}
\hline & $\mathrm{Rl} \pm$ SEM $(n)$ & $p$ \\
\hline P6-P7 & $0.607 \pm 0.051(12)$ & $* *$ \\
P8-P12 & $0.879 \pm 0.037(14)$ & + \\
P13-P14 & $0.820 \pm 0.027(7)$ & $*$ \\
P16-P19 & $0.975 \pm 0.033(9)$ & \\
\hline
\end{tabular}

Numbers in parentheses indicate the number of cells. Statistical significance (unpaired $t$ test) is as follows: ${ }^{\dagger} p>$ $0.05 ;{ }^{*} p<0.01 ;{ }^{* *} p<0.001$.

(100 ms interstimulus interval) were delivered at +50 and -60 $\mathrm{mV}$, and the quotient ("unblocking index") of the PPR at positive and negative holding potentials was calculated for most layer $2 / 3$, layer 4 , and layer $5 \mathrm{~b}$ cells in which $I / V$ curves had been recorded (see above). Unblocking indices of $>1$ (i.e., a greater PPR at positive membrane potentials) is consistent with voltage- and use-dependent relief of polyamine block. Figure $1 \mathrm{D} 1$ (top) shows example traces evoked by paired-pulse stimulation in layer $2 / 3$ pyramidal cells of a P8 and a P18 rat at $-60 \mathrm{mV}$ (black trace) and $+50 \mathrm{mV}$ (gray trace). The normalized traces (Fig. $1 \mathrm{D} 1$, bottom) superimposed almost perfectly in the P18 cell. In the P8 cell, on the contrary, the second pulse was relatively larger at $+50 \mathrm{mV}$ than at $-60 \mathrm{mV}$. Figure $1 \mathrm{D} 2$ shows the unblocking index plotted against the rectification index for layer $2 / 3$ (gray circles; $n=43$ ), layer 4 (white circles; $n=30$ ), and layer 5 (black circles; $n=39$ ) cells shown in Figure $1 A 3$. Unblocking and rectification indices were inversely correlated (solid line), with low $(<1)$ rectification indices (i.e., inward rectification) corresponding to high $(>1)$ unblocking indices.

To further verify the presence of GluR2-lacking AMPA receptors on immature layer $2 / 3$ pyramidal cell synapses, we tested two additional electrophysiological parameters. GluR2-lacking AMPA receptors have larger single-channel conductances than GluR2-containing receptors (Swanson et al., 1997). Singlechannel conductances can be estimated from whole-cell voltageclamp recordings using nonstationary fluctuation analysis (Benke et al., 2001). Briefly, currents during the decay phase of individual EPSCs deviate from the average. These fluctuations represent stochastic single-channel opening and closing events, such that the variance of current fluctuations is proportional to the single-channel conductance. We calculated the average single-channel conductances using isolated spontaneous AMPA receptor-mediated EPSCs from $10 \mathrm{~min}$ recordings in layer $2 / 3$ pyramidal cells in slices from 11 immature (P9-P11) and 7 more mature (P15 and P16) rats. Figure $2 A 1$ shows representative data from a P9 and a P15 cell with single-channel conductances of 7.07 and $3.94 \mathrm{pS}$, respectively, and Figure $1 A 2$ shows the summary data. As would be predicted for GluR2-lacking AMPA receptors, neurons from more immature rats had significantly larger average single-channel conductances than neurons from more mature animals (P9-P11: $7.01 \pm 0.58 \mathrm{pS}$, $n=11$; P15-P16: $3.58 \pm 0.44 \mathrm{pS}, n=7$; $p<0.001)$. These values are similar to those reported previously (Swanson et al., 1997; Benke et al., 1998).

As a second test, we measured the susceptibility of AMPA receptor-mediated spontaneous EPSCs to blockade by extracellular NAS (bath perfused at a concentration of $200 \mu \mathrm{M}$ ), a synthetic analog of Joro spider toxin. This class of compounds causes open-channel block of GluR2lacking AMPA and kainate receptors (Koike et al., 1997). Therefore, we expected the amplitude of spontaneous EPSCs in pyramidal cells from immature rats to decrease in the presence of NAS. EPSC amplitudes were quantified during a 5 min baseline period, during the last $5 \mathrm{~min}$ of a $10 \mathrm{~min}$ application of NAS, and in the last $5 \mathrm{~min}$ of a $10 \mathrm{~min}$ wash period. NAS susceptibility in six layer $2 / 3$ pyramidal cells of rats aged P9-P11 and five cells of rats aged P15 and P16 was compared. Because we were concerned about possible NAS-independent rundown, we also included a control group (six cells, P9-P11) in which no NAS was applied. Figure 2 B1 shows EPSCs amplitudes before, during, and after NAS application (or equivalent control periods) for all cells, and averaged example EPSCs are shown in Figure 2 B2. NAS partially blocked EPSCs only in cells from the more immature rats. The average block in P9-P11 cells was $19.9 \pm 2.8 \%(n=6 ; p<0.01)$, whereas EPSCs in vehicle (NAS free) time-matched experiments were unaffected $(3.0 \pm 1.7 \% ; n=6 ; p>0.5)$. EPSCs in cells from P15/P16 were insensitive to NAS $(3.1 \pm 4.1 \% ; n=5 ; p>0.05)$ (Fig. 2B3). Blockade by NAS of EPSCs in immature layer $2 / 3$ pyramidal cells is consistent with the presence of GluR2-lacking AMPA receptors.

Additionally, we observed that EPSCs in mature layer 2/3 neurons were significantly slower than in immature cells, whereas those in layer 5 and layer 4 neurons did not change (supplemental Fig. S1, available at www.jneurosci.org as supplemental material). Although this change is concurrent with the AMPA receptor switch, it is likely attributable to different mechanisms, such as changes in AMPA receptor subunit splice variants (Mosbacher et al., 1994; Lambolez et al., 1996; Koike et al., 2000).

\section{Colocalization of GluR2 and PSD95}

As an independent measure of the emergence of synaptic GluR2, we assessed colocalization of GluR2 and the postsynaptic glutamatergic marker protein PSD95 in layers $2 / 3$ and $5 \mathrm{~b}$ in tissue from rats aged P10, P14, and P24 using immunohistochemistry and confocal microscopy. Figure 3 shows representative images of layer 2/3 (Fig. 3A1-A3) and layer 5 (Fig. 3B1-B3) for the three ages; GluR2 immunofluorescence is shown in red, and PSD95 immunofluorescence is shown in green. The predominantly punctate staining of both GluR2 and PSD95 indicates clustering of the antigens. In the neuropil, GluR2 and PSD95 immunofluorescence intensity appears to increase between P10 and P14, but direct comparisons are difficult because antibodies might penetrate differently in tissue of different ages. The images show a larger fraction of colocalizing (yellow) GluR2- and PSD95positive puncta in P14 (Fig. 3A2) and P24 (Fig. 3A3) sections compared with P10 sections (Fig. $3 A 1$ ) in layer $2 / 3$. In layer 5 b, 
the degree of colocalization increased between P10 and P14 (Fig. 3B1,B2) and between P14 and P24 (Fig. 3B2,B3).

To quantify the position of GluR2positive puncta relative to PSD95-positive puncta, we captured stacks of 12 images $(25 \times 25 \times 5 \mu \mathrm{m}$ total stack volume $)$ and measured the density of GluR2-positive puncta in $100 \mathrm{~nm}$ shells surrounding each PSD95-positive object. If both sets of objects were distributed independently, the density of GluR2-positive puncta would remain constant in each shell. In contrast, increasing densities in the inner shells would indicate colocalization of the two antigens. Figure 3, C1 and $C 2$, shows the results from seven to nine sections from layer $2 / 3$ and layer $5 \mathrm{~b}$ of P10, P14, and P24 animals. In layer $2 / 3$, there is little colocalization of GluR2 and PSD95 at P10 but higher colocalization at P14 and P24. The density of GluR2-positive puncta was significantly increased at distances up to 300 $\mathrm{nm}$ from each PSD95-positive object in P14 and P24 tissue (Fig. 2C1). In layer 5, colocalization was moderate in sections from P10, with a small increase at P14 animals and a sharper increase by P24 (Fig. $3 C 2$ ). This is in agreement with the physiological results indicating emergence of synaptic GluR2-containing AMPA receptors around P15 in layer 5 and around P12 in layer $2 / 3$. It should be noted, though, that these experiments cannot assign a putative synapse to a particular neuronal type or its layer of origin. Layer $2 / 3$ pyramidal cells receive the majority of synaptic inputs from layer 4 (Dantzker and Callaway, 2000; Shepherd et al., 2003; Bureau et al., 2004). Thus, the putative synapses in layer $2 / 3$ would be a mixed population of intralaminar synapses and synapses of layer 4 afferents onto pyramidal cells, in addition to pyramidal cell-tointerneuron synapses. The synapses in layer 5 are likely more heterogeneous, because layer $5 \mathrm{~b}$ pyramidal cells receive extensive synaptic inputs from layers 5 and 6 but also from layers $2-5 a$ (Staiger et al., 2000; Schubert et al., 2001; Jin and Huguenard, 2006). Thus, the putative synapses in Figure $3 C 2$ comprise layer 5 intralaminar synapses and afferents from other cortical layers. We found no significant trend in either the absolute numbers or the ratios of GluR2- to PSD95-positive puncta in each analyzed slice for the three age groups (ratio ranged from $1.06 \pm 0.03$ for layer $2 / 3$ at P14 to $1.31 \pm 0.08$ for layer 5 at P10; data not shown). This demonstrates that the increasing colocalization reflects a shift in the distribution of the two antigens rather than a relative increase in the expression of one of them.

\section{Characterization of direct responses mediated by dendritic AMPA receptors}

Previous reports have suggested that, unlike synaptic AMPA receptors, somatic AMPA receptors in immature layer 5 pyramidal cells are GluR2 lacking (Kumar et al., 2002). Pyramidal cell somata are devoid of glutamatergic synapses (DeFelipe and Farinas,
1992); therefore, somatic AMPA receptors must be extrasynaptic. We wanted to extend these findings to dendritic AMPA receptors, because these can be in very close proximity to glutamatergic synapses and thus may well comprise a different pool than somatic receptors. We used focal photolysis of MNI-caged glutamate to activate dendritic receptors. Dendrites were identified by scanning across areas $\sim 100-500 \mu \mathrm{m}$ surrounding the soma of the recorded cell until focal, EPSC-like, short-latency, reproducible responses were evoked. To ensure that direct responses could be unambiguously distinguished from synaptic responses, we uncaged glutamate directly onto the soma of 19 pyramidal cells and recorded action potentials in the cell-attached mode. No action potentials were detected within the first $3 \mathrm{~ms}$ of the uncaging stimulus (data not shown). Thus, for analysis of direct responses, we considered only responses that rose within $3 \mathrm{~ms}$ of the uncaging stimulus. Figure $4 A$ shows an example of a layer 5 pyramidal cell from a P17 rat. The cell was filled with Alexa455-dextran, which allowed visualization under UV illumination (a different wavelength from that used to uncage MNI-glutamate). The top left trace in Figure $4 \mathrm{~A}$ shows a direct dendritic response evoked by uncaging onto the apical dendrite $\sim 200 \mu \mathrm{m}$ from the soma, 

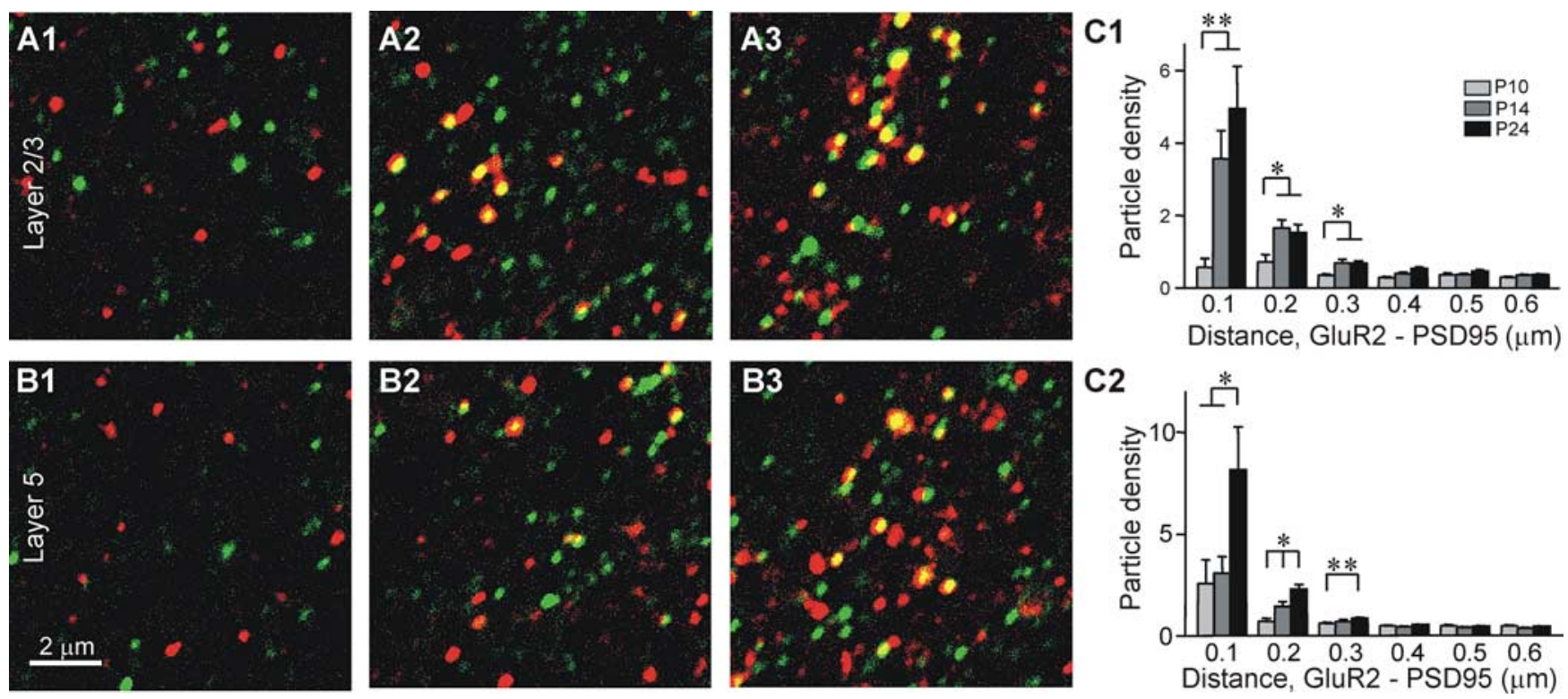

Figure 3. GluR2/PSD97 colocalization. $\boldsymbol{A}, \boldsymbol{B}$, Representative confocal images from cortical sections of P10 (A1, B1), P14 $(\boldsymbol{A 2}, \boldsymbol{B} 2)$, and P24 (A3, B3) rats. Images show $15 \times 15 \mu \mathrm{m}$ sections from layer 2/3 $(\boldsymbol{A})$ and layer $5(\boldsymbol{B})$ that were stained for PSD95 (green) and GluR2 (red). Increasing numbers of yellow puncta can be seen in sections from older animals. $\boldsymbol{C}$, Analysis of the number of GluR2-positive puncta (particles $/ \mu \mathrm{m}^{3}$ ) within $0.1 \mu \mathrm{m}$ shells of increasing radius from each PSD95-positive object for layer $2 / 3(\mathbf{C 1})$ and layer 5 (C2). Error bars indicate SEM. ${ }^{*} p<0.01 ;{ }^{* *} p<0.001$.

and the top right trace shows that this response was abolished by moving the uncaging beam $<30 \mu \mathrm{m}$ laterally. The bottom trace shows a direct response evoked by uncaging onto the soma. It had a larger amplitude and a shorter latency but similar kinetics compared with the dendritic response. Amplitudes of direct dendritic responses were predicted to be graded because they do not depend on stochastic synaptic release, with the amount of uncaged glutamate proportional to the stimulation duration and MNIglutamate concentration. We assessed whether the kinetics and amplitudes of direct dendritic responses vary with MNI-glutamate concentration and stimulation intensity, potentially as a result of local receptor saturation, desensitization, and/or diffusion of uncaged glutamate. Figure $4 B 1$ shows a representative experiment in which a layer 5 pyramidal cell from a P18 rat was exposed to combinations of three MNI-glutamate concentrations $(33,100$, and $300 \mu \mathrm{M})$ and four stimulation durations (900, 300,200 , and $100 \mu$ s). Decay constants $(\tau)$ and $50 \%$ rise times of evoked responses did not vary systematically under these conditions (top two panels), but the response amplitude increased with rising MNI-glutamate concentrations and with longer stimulation durations. Figure $4 B 2$ shows example traces at indicated times during all combinations of conditions, demonstrating changing amplitudes (top, raw traces) but similar kinetics (bottom, superimposed normalized traces). Decay constants, 50\% rise times, and amplitudes of direct dendritic responses from 10 pyramidal cells (both layers $2 / 3$ and $5 ; 100 \mu \mathrm{M}$ MNI-glutamate) are shown in Figure 4C1-C3, respectively, with stimulation durations ranging from 0.2 to $1 \mathrm{~ms}$. Again, decay constants and 50\% rise times did not vary systematically, but amplitudes increased with increasing stimulation durations. With even longer uncaging pulse durations (several milliseconds), response kinetics did slow down significantly (possibly because of overlapping stimulation and response times; data not shown). Only stimulation durations between 0.1 and $0.5 \mathrm{~ms}$ were used in subsequent experiments.

Pyramidal neurons have extended dendritic arbors, which leads to filtering and attenuation of electrical signals. This could compromise voltage-clamp fidelity and lead to an underestima- tion of rectification indices, both for direct and for synaptic responses. Figure $4 D$ shows rectification indices measured in mature layer 5 pyramidal cells evoked by direct dendritic stimulation at various distances from the soma $(100-500 \mu \mathrm{m})$. Gray circles represent results from individual cells, whereas black circles show averaged data for $100 \mu \mathrm{m}$ bins. Rectification indices remain constant within this range, indicating that voltage-clamping artifacts do not preclude determination of rectification indices for direct dendritic responses, originating within $0.5 \mathrm{~mm}$ of the soma and, by extension, for synaptic responses. Together, these results show that amplitudes of direct dendritic responses are suitable for determining $I / V$ relationships.

\section{GluR2-containing AMPA receptors predominate principal cell dendritic responses}

We measured rectification indices in apical dendrites by direct stimulation of 65 layer $2 / 3$ and 49 layer 5 pyramidal cells in slices from rats aged P8-P40. Figure 5A1 shows representative traces evoked by uncaging onto the apical dendrites of layer $2 / 3$ and layer 5 pyramidal cells of a P8 and a P19 rat; the corresponding $I / V$ curves are shown in Figure 5A2. Pyramidal cells in both layers and at both ages display slightly outwardly rectifying $I / V$ curves, typical of GluR2-containing receptors (Washburn et al., 1997). Figure $5 B$ shows all rectification indices obtained from layer $2 / 3$ (open circles) and layer 5 (filled circles) cells. No significant differences were seen between immature and mature neurons in either layer or between the two layers (Table 1), although decay kinetics slowed in more mature cells (supplemental Fig. S1, available at www.jneurosci.org as supplemental material). There was no difference in rectification indices evoked from basal and apical dendrites (P8-P12, layer 2/3: basal, $1.29 \pm 0.09, n=6$; apical, $1.13 \pm 0.07, n=11$; P8-P12, layer 5: basal, $1.35 \pm 0.05, n=4$; apical, $1.26 \pm 0.09, n=9 ; p>0.05)$. We also measured rectification indices in pyramidal cell somata, and in agreement with previous reports (Kumar et al., 2002), they were linear or slightly outwardly rectifying (data not shown). Dendritic rectification indices from layer 4 stellate cells of P6 animals were also slightly outwardly rectifying (rectification index, $1.47 \pm 0.12 ; n=4$; data 


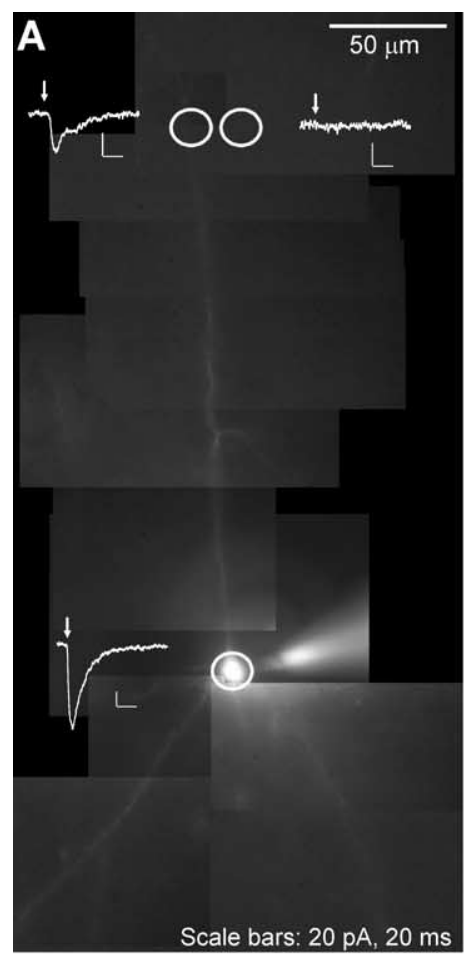

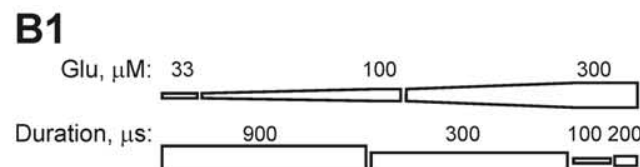
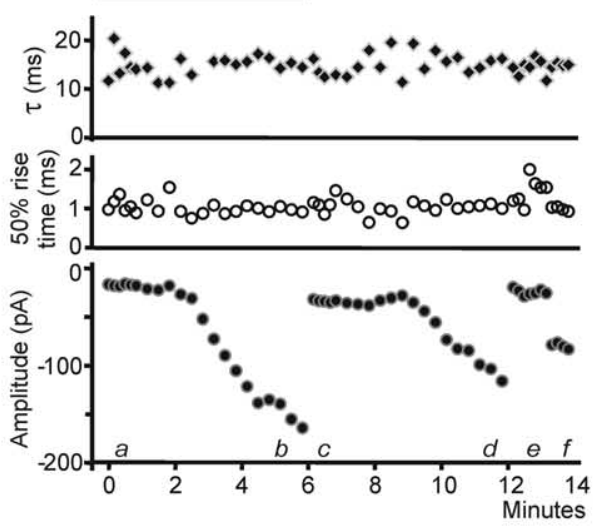

B2

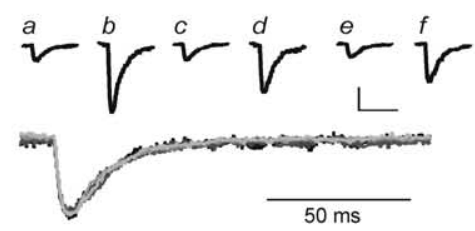

C1

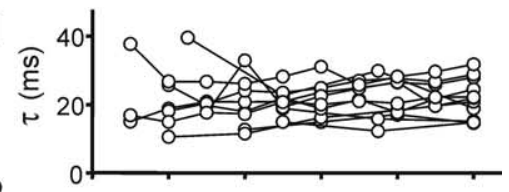

$\mathrm{C2}$

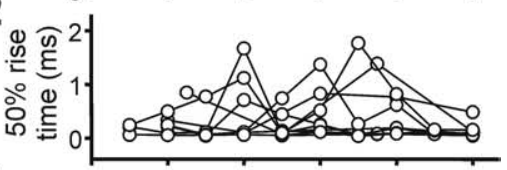

C3
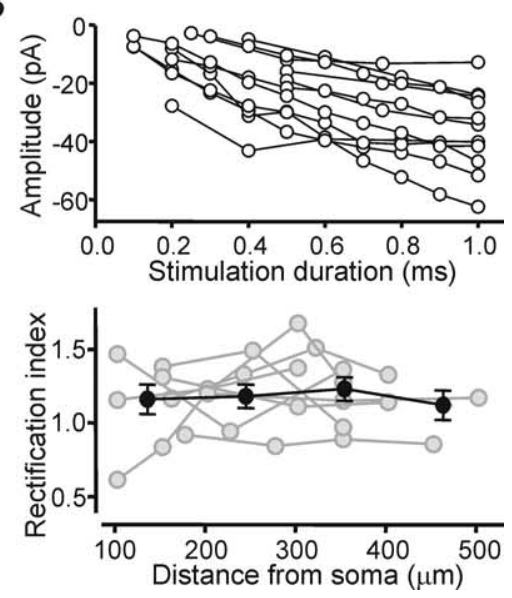

Figure 4. Characterization of direct dendritic responses. $A$, Composite image of a patched layer 5 pyramidal cell filled with Alexa455-dextran dye while recording in voltage clamp (patch pipette is to the right of the soma). The apical and two basal dendrites are visible. Circles indicate locations of focal MNI- glutamate uncaging (100 $\mu \mathrm{m}$ in bath solution). A large inward response was elicited by uncaging onto the soma (arrow indicates time of $100 \mu$ s laser pulse; bottom trace). A smaller response was obtained by uncaging onto the apical dendrite $\sim 200 \mu \mathrm{m}$ from the soma (top left circle and trace; $200 \mu$ s laser pulse) but was abolished when the uncaging focus was moved $\sim 30 \mu \mathrm{m}$ to the side of the dendrite (top right circle and trace; $200 \mu$ s laser pulse). B1, Kinetics of direct responses elicited from one spot on the apical dendrite in a layer 5 pyramidal cell of a P18 rat from a holding potential of $-60 \mathrm{mV}$. MNI- glutamate (Glu) concentrations and stimulation durations are shown on top. The starting MNI- glutamate concentration of $33 \mu \mathrm{m}$ was followed by washin of 100 and $300 \mu \mathrm{M} \mathrm{MNI-glutamate.} \mathrm{Stimulation} \mathrm{durations} \mathrm{were} \mathrm{900,} \mathrm{300,} \mathrm{100,} \mathrm{and} \mathrm{200} \mu$ s. The bottom three panels show decay constants $(\tau), 50 \%$ rise times, and maximum amplitudes of responses. Amplitudes are dependent on stimulation durations and MNI-glutamate concentrations, whereas decay and rise times are not. B2, Top, Example traces recorded at time points a through findicated above the $x$-axis in $\mathbf{C 1}$, representing all six concentration/duration combinations. Bottom, Scaled traces. Calibration: $50 \mathrm{~ms}, 50 \mathrm{pA}$. C1-C3, Decay constants (C1),50\% rise times (C2), and amplitudes (C3) of responses evoked from a holding potential of $-60 \mathrm{mV}$ at stimulation durations between $100 \mu$ s and $1 \mathrm{~ms}$. Responses from 10 layer 2/3 and layer 5 pyramidal cells from P12 and P16 rats evoked by photolysis of $100 \mu \mathrm{M} \mathrm{MNI-glutamate} \mathrm{are} \mathrm{shown.} \mathrm{Amplitudes} \mathrm{are} \mathrm{approximately}$ proportional to stimulation duration, whereas decay and rise times are unaffected. $\boldsymbol{D}$, Rectification indices were measured at various distances from the soma in five pyramidal cells to assess the potential contributions of voltage-clamping artifacts and signal attenuation. Gray circles show individually measured rectification indices between 100 and $500 \mu \mathrm{m}$ from the soma, and black circles show averaged data with $100 \mu \mathrm{m}$ binning. Error bars indicate SEM.

not shown). Whereas immature synapses of neocortical excitatory neurons express GluR2-lacking AMPA receptors, dendritic AMPA responses are dominated by GluR2-containing receptors.

Using the same glutamate uncaging protocol, we could reliably evoke inwardly rectifying responses from dendrites and somata of layer 5 fast spiking interneurons (dendrite: rectification index, $0.70 \pm 0.04, n=3$; soma: rectification index, $0.56 \pm 0.07$, $n=6$; age, P14-P15) (Fig. 5A2, inset). The linear $I / V$ curves from immature pyramidal dendrites are thus neither an experimental artifact nor a universal feature of all neuronal dendrites. Rather, they appear to represent a cell-type-specific and developmentally regulated mechanism of AMPA receptor targeting.

NMDA/AMPA ratios are greater in dendrites than in synapses and decrease during development

To further explore developmental and cell-compartmentspecific differences between dendritic and synaptic glutamate receptors, we examined the contribution of AMPA and NMDA receptors to EPSCs and direct dendritic responses (Fig. 6). Synaptic and dendritic responses were evoked in the same cells from membrane potentials of $\times 60$ and $+50 \mathrm{mV}$. At $\times 60 \mathrm{mV}$, NMDA receptors are blocked by extracellular $\mathrm{Mg}^{2+}$, but the magnesium block is relieved by depolarization. NMDA receptors activate and inactivate slowly, so that the peak response at $+50 \mathrm{mV}$ occurs at a time when AMPA receptor-mediated responses have mostly decayed ( $\sim 20 \mathrm{~ms}$ after stimulus) (Fig. $6 A)$. In agreement with a recently published report on dendritic spines of layer $2 / 3$ somatosensory cortex neurons (Busetto et al., 2008), we found a significantly higher NMDA/AMPA ratio in dendritic responses compared with EPSCs in cells from animals aged P9-P12 and P17P18 both in layer 2/3 (Fig. 6B1) (P9-P12, $n=10$ : dendrite, $6.42 \pm 0.97$; synapse, $1.31 \pm 0.19 ; p<0.001 ; \mathrm{P} 17-\mathrm{P} 18, n=9$ : dendrite, $2.34 \pm 0.55$; synapse, $0.97 \pm 0.21 ; p<0.05$, paired $t$ tests) and in layer 5b (Fig. 6B2) (P9-P12, $n=11$ : dendrite, $5.34 \pm 0.99$; synapse, $1.04 \pm 0.16 ; p<0.005 ; \mathrm{P} 17-\mathrm{P} 18, n=11$ : dendrite, $2.83 \pm 0.58$; synapse, $0.54 \pm 0.13 ; p<0.01$, paired $t$ tests). Synaptic and dendritic NMDA/AMPA ratios decreased to similar degrees between P9-P12 and P17-P18 (Fig. 6C).

\section{Discussion}

Principal neurons in many regions of the CNS express GluR2lacking synaptic AMPA receptors early in development and subsequently switch to GluR2-containing AMPA receptors. This has been shown for a number of neurons in rodents, including layer 5 pyramidal cells (Kumar et al., 2002), inner hair cell synapses (Eybalin et al., 2004), calyx of Held synapses (Joshi et al., 2004), and in the hippocampus (Ho et al., 2007). It seems to be a common developmental process that occurs not only in mammals but 


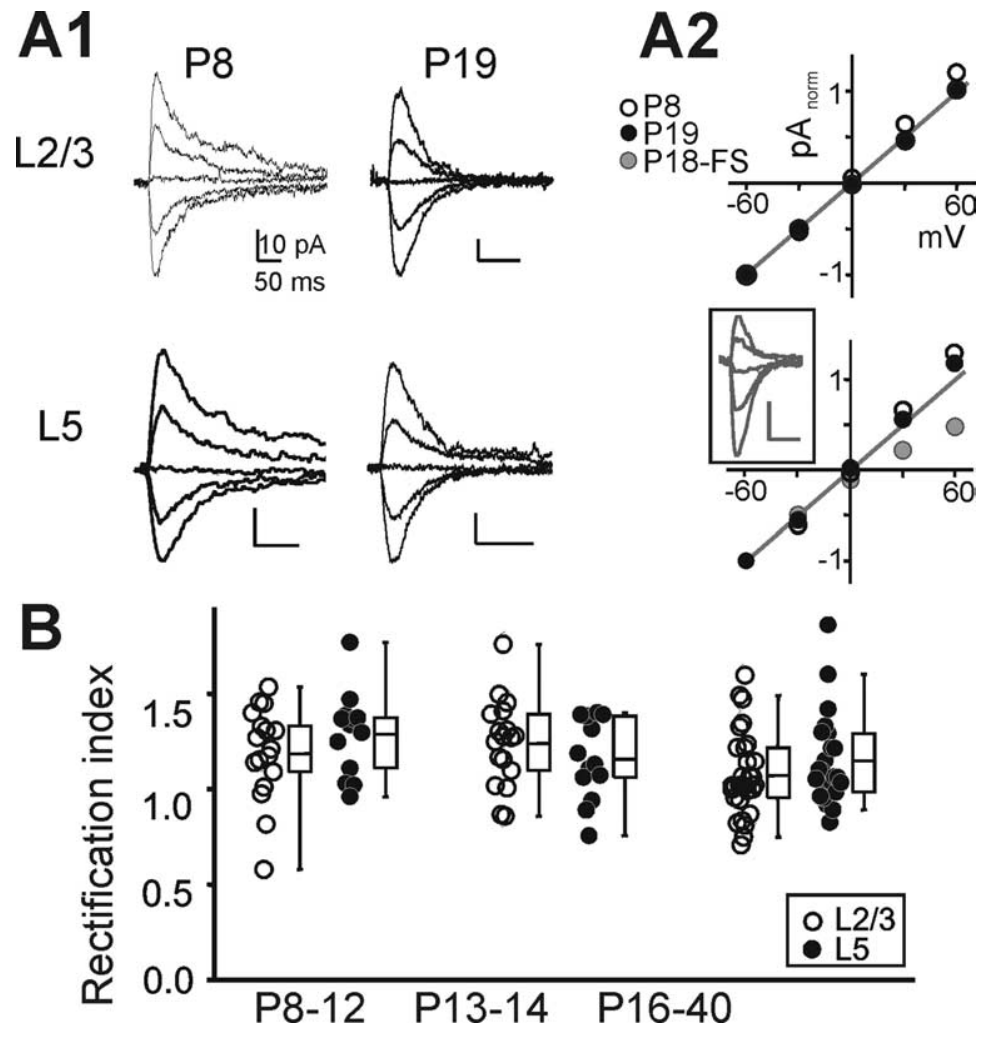

Figure 5. GluR2-containing extrasynaptic AMPA receptors. $A 1$, Representative direct dendritic responses evoked from holding potentials of $-60,-30,0,30$, and $60 \mathrm{mV}$ in layer $2 / 3(\mathrm{~L} 2 / 3)$ and layer 5 (L5) pyramidal cells of animals aged P8 and P19. Responses were evoked by focal photolysis of caged glutamate onto a dendritic location at least $100 \mu \mathrm{m}$ from the soma. Recordings were obtained with $50 \mu \mathrm{m}$ spermine in the patch pipette. Calibration: $50 \mathrm{~ms}, 10 \mathrm{pA} . \mathbf{A 2}, I / V$ curves derived from the traces shown in $\mathbf{A 1}$. Direct dendritic responses for layer $2 / 3$ (white circles) and layer 5 (black circles) pyramidal cells in both age groups were normalized to the maximal amplitude at $-60 \mathrm{mV}$. Diagonal lines were added to indicate that $/ / V$ curves were slightly outwardly rectifying. The inset shows inwardly rectifying dendritic responses at $V_{\text {hold }}$ of $-60,-30,0,30$, and 60 for dendritic responses of a layer 5 fast spiking interneuron. The corresponding $I / V$ curve is depicted by gray circles. $B$, Summary data for all dendritic rectification indices measured in layer 2/3 (L2/3; open circles) and layer 5 (L5; filled circles) cells for animals aged P8 -P12, P13-P14, and P16-P40. There is no developmental switch in rectification, indicating prevalence of GluR2-containing dendritic AMPA receptors. Error bars indicate SEM.

also in species such as zebrafish (Patten and Ali, 2007), chicken (Migues et al., 2007), and Xenopus (Aizenman et al., 2002). We show that the developmental switch from GluR2-lacking to GluR2-containing receptors also occurs in excitatory layer 2/3 and layer 4 neurons. We probed the presence of GluR2-lacking receptors using $I / V$ curves, voltage-dependent unblocking, susceptibility of spontaneous EPSCs to blockade by extracellular NAS, and single-channel conductances determined by nonstationary fluctuation analysis. All results were consistent with the presence of GluR2-lacking AMPA receptors in immature synapses. We should point out that the immature synapses probed by us, with rectification indices of $0.5-0.6$, likely contained a mixed, rather than pure, population of GluR2-lacking and GluR2contianing receptors, whereas mature synapses predominantly contained GluR2-containing receptors. Kidd and Isaac (1999) have shown that thalamocortical synapses onto developing layer 4 stellate cells in the absence of intracellular spermine have mixed fast, linear AMPA receptor-mediated and slow, inwardly rectifying kainate receptor-mediated responses. We should note that (1) we did not strictly stimulate thalamocortical fibers, such that our stimulation protocol likely stimulated both thalamocortical and intracortical axons, and (2) the inwardly rectifying responses reported here may be, at least partially, kainate receptor mediated. Kainate receptors, like GluR2-lacking AMPA receptors, are calcium permeable and inwardly rectifying in the presence of intracellular polyamines (Kamboj et al., 1995).

Neocortical layers are formed in an inside-out manner, such that excitatory neurons of deep layers are born first and superficial neurons are born, and migrate to their final position, later (for review, see Kriegstein, 2005). However, the timing of layer formation is not reflected in the "canonical neocortical circuit": thalamic inputs project mainly to layers 4 and $5 \mathrm{a}$, these project primarily to layer $2 / 3$, and layer $2 / 3$ sends a large number of efferents to layer 5b (Angevine and Sidman, 1961; Staiger et al., 2000; Petersen and Sakmann, 2001; Thomson and Bannister, 2003; Wirth and Lüscher, 2004; Douglas and Martin, 2007; Lübke and Feldmeyer, 2007; Petersen, 2007). This is obviously a simplification, especially for layer $5 b$ (there are extensive intralaminar projections, as well as afferents and efferents from other layers and other cortical areas). However, the basic circuit has been well established using laser-scanning photostimulation to map synaptic inputs to different layers (Dantzker and Callaway, 2000; Staiger et al., 2000; Schubert et al., 2001; Shepherd et al., 2003; Bureau et al., 2004), voltage-sensitive dye studies to image the spread of activation across layers (Petersen and Sakmann, 2001; Laaris and Keller, 2002), and paired recordings (Thomson and Bannister, 1998; Reyes and Sakmann, 1999; Feldmeyer et al., 2002; Thomson et al., 2002). The timing of the GluR2 switch (layer $4 \rightarrow$ layer $2 / 3 \rightarrow$ layer 5 ) corresponds to the position within the canonical neocortical circuit rather than the ontogenetic age of the layer. Layer 4 stellate cells, which receive input from thalamic relay nuclei and provide input to layer $2 / 3$ pyramidal neurons, fail to exhibit strong inward rectification after $\mathrm{P} 7$, a time when thalamocortical inputs in the somatosensory cortex are already well established (Crair and Malenka, 1995; Isaac et al., 1997; Bannister et al., 2005; Inan et al., 2006). Timing of the GluR2 switch in layer $2 / 3$ pyramidal neurons coincides with the critical period for developmental plasticity in somatosensory cortex (Stern et al., 2001). Not much is known about timing of critical period plasticity in layer $5 \mathrm{~b}$, but it is conceivable that it, too, coincides with network maturation and the GluR2 switch. Because we could not strictly stimulate only one set of afferent projections to each layer, and because the switch in layer $5 \mathrm{~b}$ occurs at the same time regardless of whether callosal, intralaminar, or supragranular stimulation was used (Kumar et al., 2002; this study), we hypothesize that the GluR2 switch occurs at specific times in each cortical layer regardless of specific afferents.

GluR2-containing receptors could be more readily excluded from immature synapses by a specific active targeting mechanism. Alternatively, there could be a passive mechanism in which GluR2 expression slowly increases, creating a delay for GluR2containing receptors to be trafficked into more and more distal synapses. If GluR2-lacking receptors slowly diffused "out into the 
dendrites," the smaller size of layer $2 / 3$ and layer 4 neurons could account for the earlier switch. We believe that our results argue for an active targeting mechanism. First, the linear $I / V$ relationships of dendritic AMPA receptor-mediated responses in immature neurons indicate that GluR2containing receptors are present at locations up to $0.5 \mathrm{~mm}$ from the soma, such that a significant proportion of synaptic AMPA receptors of immature neurons are GluR2 lacking, whereas dendritic receptors in the same cells are not. Second, as shown in Figure $4 D$, there was no correlation between rectification indices and distance of glutamate release from the soma. Finally, GluR2 and the postsynaptic glutamatergic marker protein PSD95 showed a greater degree of immunohistochemical colocalization in cortical sections from more mature animals, although GluR2positive puncta are clearly present earlier. In addition, previous reports have consistently shown that trafficking of distinct AMPA receptor subtypes into and out of synapses is tightly regulated and essential in responding to changes in synaptic activity (for review, see Sprengel, 2006; Greger and Esteban, 2007; Isaac et al., 2007).

We demonstrate that focal photolysis of caged glutamate is suitable to probe extrasynaptic receptors in intact neocortical neurons in brain slices because it does not appear to activate significant proportions of synaptic receptors. This might result from several factors, for example the anatomy of the synaptic cleft, which may not allow efficient access to exogenously released glutamate, efficient glial glutamate uptake might occur in the vicinity of synapses, or extrasynaptic receptors might greatly outnumber synaptic receptors.

Extrasynaptic AMPA receptors can serve as a reserve pool for the experience- and activity-dependent modulation of synaptic receptor populations (Adesnik et al., 2005), but there may be more direct roles in regulating dendritic excitability. Extrasynaptic glutamate receptors have been reported to sense and react to extracellular glutamate levels via synaptic spillover (Asztely et al., 1997) and autoexcitation (Nicoll and Jahr, 1982) and to be involved in glia-to-neuron signaling (for review, see (Fellin et al., 2006). AMPA receptors desensitize quickly, have low glutamate affinities compared with NMDA receptors, and are thus unlikely to be major effectors for slowly released glutamate at concentrations much lower than those found in the synaptic cleft. At present, only very few reports indicate a direct physiological role for nonsynaptic AMPA receptors, for example in lateral excitation of mitral cells (Urban and Sakmann, 2002) or in neuron-toglia signaling between Bergmann glia and climbing fiber and parallel fiber synapses (Clark and Barbour, 1997).

Additionally, we characterized NMDA/AMPA ratios, which display striking differences between dendritic and synaptic compartments. We found a much larger NMDA component in dendrites, supporting the notion that NMDA receptors play a more prominent role in extrasynaptic glutamate signaling (for review, see Vizi and Mike, 2006). We also shown that the NMDA/AMPA ratio decreased by similar degrees in dendrites and synapses during development. This is in agreement with a recently published report using two-photon glutamate uncaging onto dendritic spines of layer $2 / 3$ pyramidal neurons, in which the authors found a decrease in NMDA/AMPA ratios around P12, possibly caused by a decrease in silent (i.e., AMPA receptor-lacking) synapses (Busetto et al., 2008). Again, the timing of this NMDA/ AMPA ratio decrease coincides with the GluR2 switch. NMDA receptors and GluR2-lacking AMPA receptors are calcium permeable, suggesting that both developmental switches limit calcium influx into maturing pyramidal cells.

In this study, we have expanded on findings that describe a developmental switch in neocortical principal neurons from GluR2-lacking to GluR2-containing synaptic AMPA receptors. Simultaneously, synaptic and dendritic NMDA/AMPA ratios of pyramidal cells are downregulated. We also validate a method to activate dendritic, extrasynaptic receptors by focal photolysis of caged glutamate and show that dendritic receptors in immature cortical neurons differ from synaptic receptors at similar distances from the soma: dendritic receptors are GluR2 containing, and synaptic receptors are GluR2 lacking. Thus, neocortical synaptic maturation coincides with a shift in AMPA receptor targeting, which proceeds sequentially from layer 4 to layer $2 / 3$ to layer $5 b$. 


\section{References}

Adesnik H, Nicoll RA, England PM (2005) Photoinactivation of native AMPA receptors reveals their real-time trafficking. Neuron 48:977-985.

Aizenman CD, Munoz-Elias G, Cline HT (2002) Visually driven modulation of glutamatergic synaptic transmission is mediated by the regulation of intracellular polyamines. Neuron 34:623-634.

Angevine JB Jr, Sidman RL (1961) Autoradiographic study of cell migration during histogenesis of cerebral cortex in the mouse. Nature 192:766-768.

Asztely F, Erdemli G, Kullmann DM (1997) Extrasynaptic glutamate spillover in the hippocampus: dependence on temperature and the role of active glutamate uptake. Neuron 18:281-293.

Bagal AA, Kao JP, Tang CM, Thompson SM (2005) Long-term potentiation of exogenous glutamate responses at single dendritic spines. Proc Natl Acad Sci U S A 102:14434-14439.

Bannister NJ, Benke TA, Mellor J, Scott H, Gurdal E, Crabtree JW, Isaac JT (2005) Developmental changes in AMPA and kainate receptor-mediated quantal transmission at thalamocortical synapses in the barrel cortex. J Neurosci 25:5259-5271.

Benke TA, Lüthi A, Isaac JT, Collingridge GL (1998) Modulation of AMPA receptor unitary conductance by synaptic activity. Nature 393:793-797.

Benke TA, Luthi A, Palmer MJ, Wikstrom MA, Anderson WW, Isaac JT, Collingridge GL (2001) Mathematical modelling of non-stationary fluctuation analysis for studying channel properties of synaptic AMPA receptors. J Physiol (Lond) 537:407-420.

Bureau I, Shepherd GM, Svoboda K (2004) Precise development of functional and anatomical columns in the neocortex. Neuron 42:789-801.

Busetto G, Higley MJ, Sabatini BL (2008) Developmental presence and disappearance of postsynaptically silent synapses on dendritic spines of rat layer 2/3 pyramidal neurons. J Physiol (Lond) 586:1519-1527.

Chetkovich DM, Chen L, Stocker TJ, Nicoll RA, Bredt DS (2002) Phosphorylation of the postsynaptic density-95 (PSD-95)/discs large/zona occludens- 1 binding site of stargazin regulates binding to PSD-95 and synaptic targeting of AMPA receptors. J Neurosci 22:5791-5796.

Clark BA, Barbour B (1997) Currents evoked in Bergmann glial cells by parallel fibre stimulation in rat cerebellar slices. J Physiol (Lond) 502: 335-350.

Crair MC, Malenka RC (1995) A critical period for long-term potentiation at thalamocortical synapses. Nature 375:325-328.

Dantzker JL, Callaway EM (2000) Laminar sources of synaptic input to cortical inhibitory interneurons and pyramidal neurons. Nat Neurosci 3:701-707.

DeFelipe J, Farinas I (1992) The pyramidal neuron of the cerebral cortex: morphological and chemical characteristics of the synaptic inputs. Prog Neurobiol 39:563-607.

Deleuze C, Huguenard JR (2006) Distinct electrical and chemical connectivity maps in the thalamic reticular nucleus: potential roles in synchronization and sensation. J Neurosci 26:8633-8645.

Dingledine R, Borges K, Bowie D, Traynelis SF (1999) The glutamate receptor ion channels. Pharmacol Rev 51:7-61.

Douglas RJ, Martin KA (2007) Mapping the matrix: the ways of neocortex. Neuron 56:226-238.

Esteban JA, Shi SH, Wilson C, Nuriya M, Huganir RL, Malinow R (2003) PKA phosphorylation of AMPA receptor subunits controls synaptic trafficking underlying plasticity. Nat Neurosci 6:136-143.

Eybalin M, Caicedo A, Renard N, Ruel J, Puel JL (2004) Transient Ca2 +permeable AMPA receptors in postnatal rat primary auditory neurons. Eur J Neurosci 20:2981-2989.

Feldmeyer D, Egger V, Lubke J, Sakmann B (1999) Reliable synaptic connections between pairs of excitatory layer 4 neurones within a single "barrel" of developing rat somatosensory cortex. J Physiol (Lond) 521:169-190

Feldmeyer D, Lübke J, Silver RA, Sakmann B (2002) Synaptic connections between layer 4 spiny neurone-layer $2 / 3$ pyramidal cell pairs in juvenile rat barrel cortex: physiology and anatomy of interlaminar signalling within a cortical column. J Physiol (Lond) 538:803-822.

Fellin T, Sul JY, D’Ascenzo M, Takano H, Pascual O, Haydon PG (2006) Bidirectional astrocyte-neuron communication: the many roles of glutamate and ATP. Novartis Found Symp 276:208-217.

Greger IH, Esteban JA (2007) AMPA receptor biogenesis and trafficking. Curr Opin Neurobiol 17:289-297.

Guire ES, Oh MC, Soderling TR, Derkach VA (2008) Recruitment of calcium-permeable AMPA receptors during synaptic potentiation is regulated by CaM-kinase I. J Neurosci 28:6000-6009.

Hayashi Y, Shi SH, Esteban JA, Piccini A, Poncer JC, Malinow R (2000) Driving AMPA receptors into synapses by LTP and CaMKII: requirement for GluR1 and PDZ domain interaction. Science 287:2262-2267.

Ho MT, Pelkey KA, Topolnik L, Petralia RS, Takamiya K, Xia J, Huganir RL, Lacaille JC, McBain CJ (2007) Developmental expression of Ca2+permeable AMPA receptors underlies depolarization-induced long-term depression at mossy fiber CA3 pyramid synapses. J Neurosci 27:11651-11662.

Hollmann M, Hartley M, Heinemann S (1991) Ca2 + permeability of KAAMPA-gated glutamate receptor channels depends on subunit composition. Science 252:851-853.

Inan M, Lu HC, Albright MJ, She WC, Crair MC (2006) Barrel map development relies on protein kinase A regulatory subunit II beta-mediated cAMP signaling. J Neurosci 26:4338-4349.

Isaac JT, Crair MC, Nicoll RA, Malenka RC (1997) Silent synapses during development of thalamocortical inputs. Neuron 18:269-280.

Isaac JT, Ashby M, McBain CJ (2007) The role of the GluR2 subunit in AMPA receptor function and synaptic plasticity. Neuron 54:859-871.

Jin X, Prince DA, Huguenard JR (2006) Enhanced excitatory synaptic connectivity in layer $\mathrm{v}$ pyramidal neurons of chronically injured epileptogenic neocortex in rats. J Neurosci 26:4891-4900.

Joshi I, Shokralla S, Titis P, Wang LY (2004) The role of AMPA receptor gating in the development of high-fidelity neurotransmission at the calyx of Held synapse. J Neurosci 24:183-196.

Kamboj SK, Swanson GT, Cull-Candy SG (1995) Intracellular spermine confers rectification on rat calcium-permeable AMPA and kainate receptors. J Physiol (Lond) 486:297-303.

Keinanen K, Wisden W, Sommer B, Werner P, Herb A, Verdoorn TA, Sak mann B, Seeburg PH (1990) A family of AMPA-selective glutamate receptors. Science 249:556-560.

Kidd FL, Isaac JT (1999) Developmental and activity-dependent regulation of kainate receptors at thalamocortical synapses. Nature 400:569-573.

Koh DS, Geiger JR, Jonas P, Sakmann B (1995) Ca(2+)-permeable AMPA and NMDA receptor channels in basket cells of rat hippocampal dentate gyrus. J Physiol (Lond) 485:383-402.

Koike M, Iino M, Ozawa S (1997) Blocking effect of 1-naphthyl acetyl spermine on $\mathrm{Ca}^{2+}$-permeable AMPA receptors in cultured rat hippocampal neurons. Neurosci Res 29:27-36.

Koike M, Tsukada S, Tsuzuki K, Kijima H, Ozawa S (2000) Regulation of kinetic properties of GluR2 AMPA receptor channels by alternative splicing. J Neurosci 20:2166-2174.

Kriegstein AR (2005) Constructing circuits: neurogenesis and migration in the developing neocortex. Epilepsia 46:15-21.

Kumar SS, Bacci A, Kharazia V, Huguenard JR (2002) A developmental switch of AMPA receptor subunits in neocortical pyramidal neurons. J Neurosci 22:3005-3015.

Laaris N, Keller A (2002) Functional independence of layer IV barrels. J Neurophysiol 87:1028-1034.

Lambolez B, Ropert N, Perrais D, Rossier J, Hestrin S (1996) Correlation between kinetics and RNA splicing of alpha-amino-3-hydroxy-5methylisoxazole-4-propionic acid receptors in neocortical neurons. Proc Natl Acad Sci U S A 93:1797-1802.

Larsen DD, Callaway EM (2006) Development of layer-specific axonal arborizations in mouse primary somatosensory cortex. J Comp Neurol 494:398-414

Liu SJ, Cull-Candy SG (2005) Subunit interaction with PICK and GRIP controls $\mathrm{Ca} 2+$ permeability of AMPARs at cerebellar synapses. Nat Neurosci 8:768-775.

Lübke J, Feldmeyer D (2007) Excitatory signal flow and connectivity in a cortical column: focus on barrel cortex. Brain Struct Funct 212:3-17.

Mano I, Teichberg VI (1998) A tetrameric subunit stoichiometry for a glutamate receptor-channel complex. Neuroreport 9:327-331.

Matsuda S, Mikawa S, Hirai H (1999) Phosphorylation of serine-880 in GluR2 by protein kinase C prevents its $\mathrm{C}$ terminus from binding with glutamate receptor-interacting protein. J Neurochem 73:1765-1768.

Mauceri D, Cattabeni F, Di Luca M, Gardoni F (2004) Calcium/ calmodulin-dependent protein kinase II phosphorylation drives synapseassociated protein 97 into spines. J Biol Chem 279:23813-23821.

Migues PV, Cammarota M, Kavanagh J, Atkinson R, Powis DA, Rostas JA (2007) Maturational changes in the subunit composition of AMPA re- 
ceptors and the functional consequences of their activation in chicken forebrain. Dev Neurosci 29:232-240.

Mosbacher J, Schoepfer R, Monyer H, Burnashev N, Seeburg PH, Ruppersberg JP (1994) A molecular determinant for submillisecond desensitization in glutamate receptors. Science 266:1059-1062.

Nicoll RA, Jahr CE (1982) Self-excitation of olfactory bulb neurones. Nature 296:441-444.

Patten SA, Ali DW (2007) AMPA receptors associated with zebrafish Mauthner cells switch subunits during development. J Physiol (Lond) 581:1043-1056.

Petersen CC (2007) The functional organization of the barrel cortex. Neuron 56:339-355.

Petersen CC, Sakmann B (2001) Functionally independent columns of rat somatosensory barrel cortex revealed with voltage-sensitive dye imaging. J Neurosci 21:8435-8446.

Plant K, Pelkey KA, Bortolotto ZA, Morita D, Terashima A, McBain CJ, Collingridge GL, Isaac JT (2006) Transient incorporation of native GluR2-lacking AMPA receptors during hippocampal long-term potentiation. Nat Neurosci 9:602-604.

Reyes A, Sakmann B (1999) Developmental switch in the short-term modification of unitary EPSPs evoked in layer 2/3 and layer 5 pyramidal neurons of rat neocortex. J Neurosci 19:3827-3835.

Rosenmund C, Stern-Bach Y, Stevens CF (1998) The tetrameric structure of a glutamate receptor channel. Science 280:1596-1599.

Rozov A, Burnashev N (1999) Polyamine-dependent facilitation of postsynaptic AMPA receptors counteracts paired-pulse depression. Nature 401:594-598.

Schubert D, Staiger JF, Cho N, Kötter R, Zilles K, Luhmann HJ (2001) Layer-specific intracolumnar and transcolumnar functional connectivity of layer V pyramidal cells in rat barrel cortex. J Neurosci 21:3580-3592.

Shepherd GM, Pologruto TA, Svoboda K (2003) Circuit analysis of experience-dependent plasticity in the developing rat barrel cortex. Neuron 38:277-289.

Shin J, Shen F, Huguenard JR (2005) Polyamines modulate AMPA receptor-dependent synaptic responses in immature layer $\mathrm{V}$ pyramidal neurons. J Neurophysiol 93:2634-2643.
Soto D, Coombs ID, Kelly L, Farrant M, Cull-Candy SG (2007) Stargazin attenuates intracellular polyamine block of calcium-permeable AMPA receptors. Nat Neurosci 10:1260-1267.

Sprengel R (2006) Role of AMPA receptors in synaptic plasticity. Cell Tissue Res 326:447-455.

Staiger JF, Kötter R, Zilles K, Luhmann HJ (2000) Laminar characteristics of functional connectivity in rat barrel cortex revealed by stimulation with caged-glutamate. Neurosci Res 37:49-58.

Stern EA, Maravall M, Svoboda K (2001) Rapid development and plasticity of layer 2/3 maps in rat barrel cortex in vivo. Neuron 31:305-315.

Swanson GT, Kamboj SK, Cull-Candy SG (1997) Single-channel properties of recombinant AMPA receptors depend on RNA editing, splice variation, and subunit composition. J Neurosci 17:58-69.

Thomson AM, Bannister AP (1998) Postsynaptic pyramidal target selection by descending layer III pyramidal axons: dual intracellular recordings and biocytin filling in slices of rat neocortex. Neuroscience 84:669-683.

Thomson AM, Bannister AP (2003) Interlaminar connections in the neocortex. Cereb Cortex 13:5-14.

Thomson AM, West DC, Wang Y, Bannister AP (2002) Synaptic connections and small circuits involving excitatory and inhibitory neurons in layers $2-5$ of adult rat and cat neocortex: triple intracellular recordings and biocytin labelling in vitro. Cereb Cortex 12:936-953.

Urban NN, Sakmann B (2002) Reciprocal intraglomerular excitation and intra- and interglomerular lateral inhibition between mouse olfactory bulb mitral cells. J Physiol (Lond) 542:355-367.

Verdoorn TA, Burnashev N, Monyer H, Seeburg PH, Sakmann B (1991) Structural determinants of ion flow through recombinant glutamate receptor channels. Science 252:1715-1718.

Vizi ES, Mike A (2006) Nonsynaptic receptors for GABA and glutamate. Curr Top Med Chem 6:941-948.

Washburn MS, Numberger M, Zhang S, Dingledine R (1997) Differential dependence on GluR2 expression of three characteristic features of AMPA receptors. J Neurosci 17:9393-9406.

Wirth C, Lüscher HR (2004) Spatiotemporal evolution of excitation and inhibition in the rat barrel cortex investigated with multielectrode arrays. J Neurophysiol 91:1635-1647. 